ENTREPRENEURSHIP AND SUSTAINABILITY ISSUES

ISSN 2345-0282 (online) http://jssidoi.org/jesi/

2019 Volume 7 Number 2 (December)

http://doi.org/10.9770/jesi.2020.7.2(12)

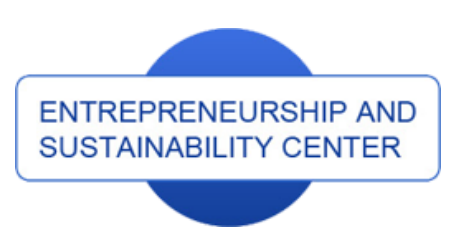

Publisher

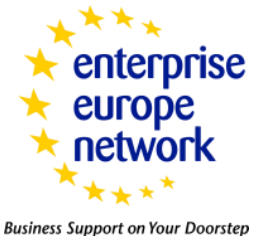

CASPA
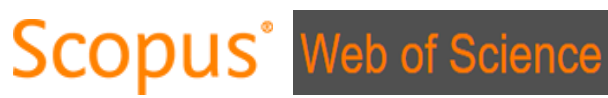

http://jssidoi.org/esc/home

1 Clarivate

Analytics

\title{
OBSTACLES AND SUCCESS FACTORS FOR ENTREPRENEURSHIP: A COMPARATIVE ANALYSIS BETWEEN EGYPT AND NIGERIA
}

\author{
Osama Wagdi ${ }^{1 *}$, Amira Hasaneen ${ }^{2}$ \\ ${ }^{1}$ Financial Institutions Department, Faculty of Management, Modern University for Technology and Information, \\ El-Hadaba El Wosta, Zone 5, Modern University st., Cairo, Egypt \\ ${ }^{2}$ Accounting Departments, Faculty of Management, Modern University for Technology and Information, \\ El-Hadaba El Wosta, Zone 5, Modern University st., Cairo, Egypt
}

E-mails: $:^{*}$ osamawagdi_ta@yahoo.com (corresponding author); ${ }^{2}$ seven.colours200@gmail.com

Received 10 August 2019; accepted 20 September 2019; published 15 December 2019

\begin{abstract}
This study investigates the obstacles and success for entrepreneurship at Africa The study also provides a framework for determinants of entrepreneurship that includes three groups of factors: (1) obstacle factors, which include financial and non-financial obstacles; (2) success factors, which include gaining an understanding of the economic environment, determining market gaps, ensuring capital adequacy, and creating a stable cash flow; and (3) business model characteristics, which include benefits for clients, suppliers, founders, investors, and other stakeholders. The study hypothesizes hat there is a relationship between the second and third groups, which creating a new value chain (tangible or intangible) to the society with support from stakeholders. A questionnaire survey was conducted with founders, investors, corporate managers, financial analysts, academics, and graduates who seek new projects from Egypt and Nigeria, and 395 questionnaires were received in the second half of 2018. The study found a difference in entrepreneurship nonbanking and non-financial obstacles between Egypt and Nigeria. This can be explained by differences in the level of efficiency of the stock exchanges and non-banking services, in addition to the differences in legal environments and levels of corruption between Egypt and Nigeria. Moreover, future directions of entrepreneurship are similar across countries, but age has an impact on these directions.
\end{abstract}

Keywords: entrepreneurship; business model; entrepreneurship obstacles; entrepreneurship success; Egypt; Nigeria

Reference to this paper should be made as follows: Wagdi, O., Hasaneen, A. 2019. Obstacles and success factors for entrepreneurship: a comparative analysis between Egypt and Nigeria. Entrepreneurship and Sustainability Issues, 7(2), 962-976. http://doi.org/10.9770/jesi.2019.7.2(12)

JEL Classifications: M13, L22, L26 


\section{ENTREPRENEURSHIP AND SUSTAINABILITY ISSUES}

ISSN 2345-0282 (online) http://jssidoi.org/jesi/

2019 Volume 7 Number 2 (December)

http://doi.org/10.9770/jesi.2019.7.2(12)

\section{Introduction}

\subsection{Background}

People have many career options after graduating or gaining professional experience. Some choose to start their own businesses. The process of creating and managing a business to achieve the desired objectives is the basis of entrepreneurship. The ability to see emerging trends and create a business that satisfies consumer needs or creates new markets is the first step towards entrepreneurship.

Some global examples of entrepreneurship include Alibaba.com, Facebook, Google, and Uber, while some examples in the African context include 57357 Hospital, Careem, Glowork, and Vezeeta.com, there are diverse types of entrepreneurship for the provision of services and products, whether they are for profit (the majority) or non-profit (rare cases). Today, many universities offer entrepreneurship courses; however, not all entrepreneurs succeed.

Finlliy, this study help an African governments and international organizations to effective implementation of entrepreneurial support program, through creating a new value chain at thire society (this value be a tangible and intangible) get stakeholder support.

\subsection{Literature review}

Since the middle of the 1900s, there have been many developments in the business environment, in both international and local business, due to changes in technology in general and information technology in particular. This has helped to increase business opportunities for small and medium-sized enterprises (SMEs) through economies of scale.

After the spread of Internet services and mobile networks through 3G, many new terms such as the following have emerged: financial technology (FinTech), digital banking (BankTech), anti-money laundering (AML), combating terrorist financing (CFT), digital currencies (CoinTech), and regulatory technology (RegTech). Thus, the business environment has become more dynamic, and this has created a new range of opportunities and threats for business units.

According to Lee et al. (2012), globalization has provided SMEs with new creative capacities to alter business models. However, the difference between the old and new business models is not evident. Therefore, there is often confusion between the concepts of SMEs and entrepreneurship (see Ríos-Manríquez et al., 2018). According to the conceptual framework by Covin and Slevin (1991), 'Entrepreneurship is described as a dimension of strategic posture represented by a firm's risk-taking propensity, tendency to act in competitively aggressive, proactive manners, and reliance on frequent and extensive product innovation'. However, the current study defines entrepreneurship as innovative and creative activities that seek to create benefits through the organization (which seeks to profit or non-profit) under its operations. In terms of strategic positioning, it aims to fulfil consumers' needs and gain competitive advantages by providing a product (good or service) that adds value for its stakeholders by creating a new value chain (tangible or intangible) in the society. The current study agrees with the findings of Covin and Slevin (1991) on the importance of strategic positioning, but not on the importance of the risk takers' attitude. This study adds a new dimension; it is the value chain tangible and intangible at the society in the concept of entrepreneurship.

SMEs, on the other hand, are not characterized by the addition of a value chain to the society. They are often replicated for other enterprises such as franchises. Therefore, SMEs in a loop in a value chain already exist. This is indirectly consistent with the results of Kuivalainen et al. (2012), who conducted a comparison between contemporary SMEs and the same SMEs from 10 years ago to examine how companies alter their designs. Such 


\section{ENTREPRENEURSHIP AND SUSTAINABILITY ISSUES}

ISSN 2345-0282 (online) http://jssidoi.org/jesi/

2019 Volume 7 Number 2 (December)

http://doi.org/10.9770/jesi.2019.7.2(12)

changes are also determined by the global direction, development direction, capacity of communication, capacity for information production, and standardization of the marketing mix.

There are many obstacles and success factors for entrepreneurship (Timmons, 1978; McClelland, 1987; Ensher et al., 2000; Donald and Goldsby, 2004; Bitzenis and Nito, 2005; Fatoki and Chindoga, 2011; Ramoglou and Tsang, 2017; Sofer and Saada, 2017). What are the entrepreneurship obstacles? In what scenario can entrepreneurship succeed phenomenally? Phenomenal or large-scale success indicates rather strong economic growth, largely attributable to entrepreneurship (Lordkipanidze et al., 2005). Financial shortage is one of the main limitations of entrepreneurship, and it is a common obstacle identified by studies related to entrepreneurship. This study classifies financial obstacles into those that originate from banks and from other financial companies such as leasing companies.

This study does not agree with the results of Ghouse et al. (2019), who identified company requirements for entry by the government, availability of dedicated providers to stay ahead of competition, and elevated prices of raw materials. All these obstacles are related to economies of scale and enterprise size and not to entrepreneurship. This criticism can be explained by the fact that these factors are not only related to entrepreneurship, but also to the business environment, SMEs also represent these obstacles.

Another obstacle is lack of skills, such as management, accounting, analytics, creative, and negotiation skills. Therefore, the need for training and the existence of certain deficiencies in human skills are obstacles (Ladzani and Van Vuuren, 2002). That agrees with Kojo Oseifuah (2010). Students will obtain information and discover about their entrepreneurial skills that is effects of entrepreneurship education (Von Graevenitz et al., 2010). Development of these skills involves not only training but also education and family support (Adjei et al., 2019). Family relationships impact entrepreneurs' performance, and, according to Hendrajaya et al. (2019), although males are affected more by other males, females are affected more by other females, according to Markussen and Røed (2017) education increases students' entrepreneurial interest. In other words, entrepreneurship must be able to address the difficulties that new entrepreneurs face in achieving success by developing different skills (Tripathy, 2019). The education and training on entrepreneurial entry increases the long-term probability of startup as well as entrepreneurial incomes, but no effect on enterprise survival (Elert et. al, 2015).

Governments seek to support entrepreneurship to create jobs, increase competition, and finally create wealth for individuals and countries (Michael and Pearce, 2009). However, is this support consistent and identical across countries? This study believes that this is not so. Because government policies and types of incentives vary across countries, according on fiscal and monetary policies in a country, as well as different business environment and business cycle status among in this country. Very few studies (Jones and Butler, 1992; Kwong et al., 2019) have examined the dark side of entrepreneurship - the psychological dimension-involving, for example, cruel experiences during wars and the agency problem. So, the study going to investigation some of these dimensions.

In addition, study compares entrepreneurship between more than one African country, where the previous study included one country. (Peberdy, 2000; Ladzani and Van Vuuren, 2002; Robson et. al., 2009; Kojo Oseifuah, 2010; Hattab, 2014; Abou-Warda, 2016; Dakung et. al., 2017; Chikha and Jarboui, 2018; Salem and Mobarak, 2019).

\subsection{Study problem}

Based on the literature review, this study provides a framework (Figure 1) for determinants of entrepreneurship that constitutes three groups of factors. The first, obstacle factors, include banking, non-banking, and nonfinancial obstacles. The second, success factors, involve understanding the economic environment, determining market gaps, ensuring capital adequacy, and creating a stable cash flow. The third, business model characteristics, 
include benefits for clients, suppliers, founders, investors, and stockholders. This study believes there is a relationship between the second and third groups, which adds value chain to the society. This new value chain, whether tangible or intangible, is the motivation behind success, by meeting the desire of customers through a different methodology that did not exist beforehand. This value chain Possible be lower costs of acquiring products or introducing a different product which increases customer satisfaction, it has led market forces to move towards this business model with support from stakeholders.

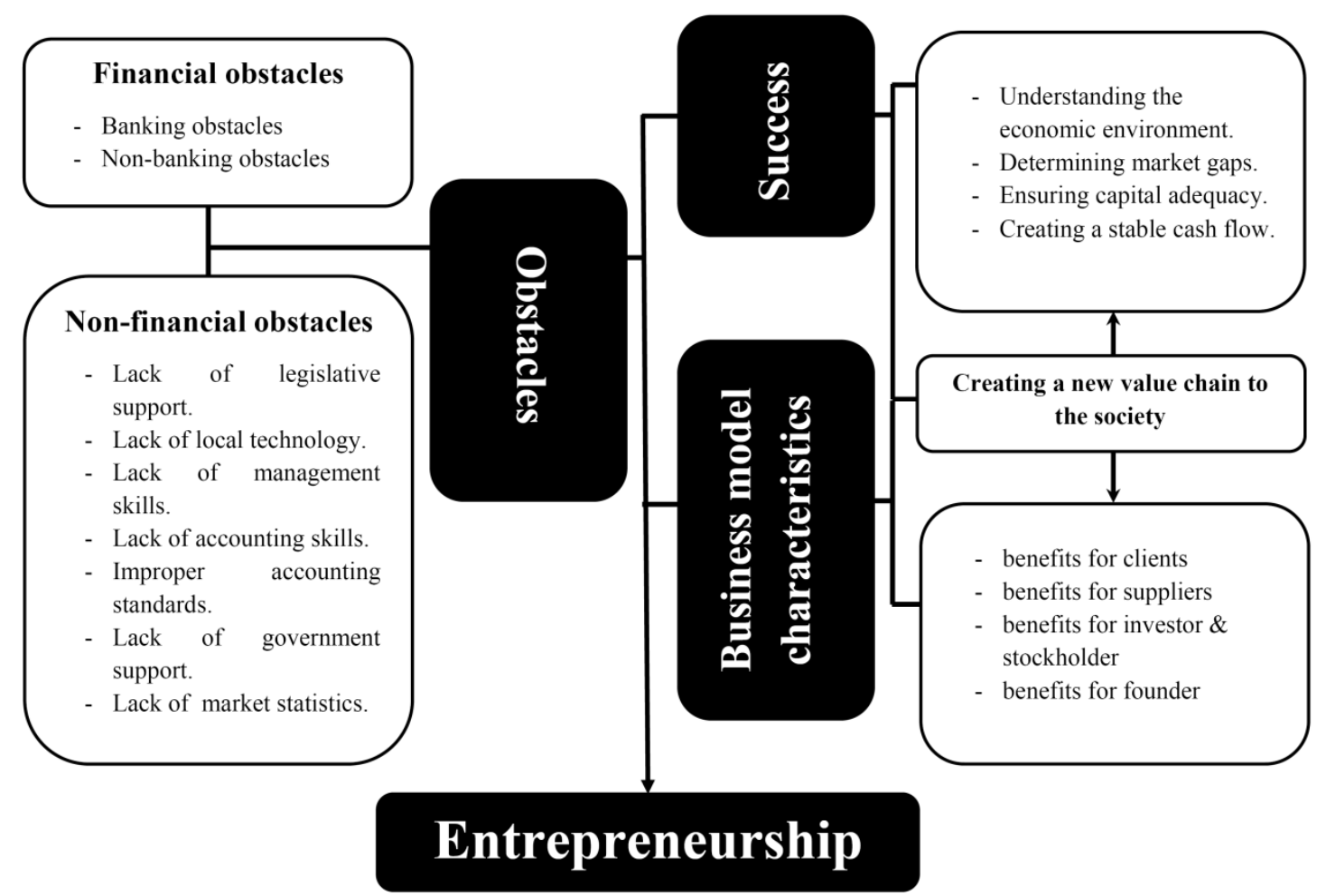

Figure 1. Framework for determinants of entrepreneurship Source: Authors

Figure 1 shows that there are three sets of factors that influence entrepreneurship. Considering that the society includes Egypt and Nigeria, the study problem can be identified as follows:

a. What are the entrepreneurship obstacles in Africa in general and in Egypt and Nigeria in particular?

b. Are there differences in the entrepreneurship obstacles in Egypt and Nigeria?

c. What are the entrepreneurship success factors in Africa in general and in Egypt and Nigeria in particular?

d. Are entrepreneurship success factors different between Egypt and Nigeria?

e. What are the business model characteristics for entrepreneurship success in Africa in general and in Egypt and Nigeria in particular?

f. Are there differences in the business model characteristics for entrepreneurship success in Egypt and Nigeria?

The following are additional questions to be addressed:

g. What are the future directions of entrepreneurship in Africa in general and in Egypt and Nigeria in particular?

h. Are the future directions of entrepreneurship different between Egypt and Nigeria?

i. Are the future directions of entrepreneurship different according to age? 


\subsection{Hypotheses}

Based on the study problem and the literature review, the following hypotheses are presented:

$\mathrm{H}_{1}$ : There is a significant difference in entrepreneurship banking obstacles between Egypt and Nigeria.

$\mathrm{H}_{2}$ : There is a significant difference in entrepreneurship non-banking obstacles between Egypt and Nigeria.

$\mathrm{H}_{3}$ : There is a significant difference in entrepreneurship non-financial obstacles between Egypt and Nigeria.

$\mathrm{H}_{4}$ : There is a significant difference in entrepreneurship success factors between Egypt and Nigeria.

$\mathrm{H}_{5}$ : There is a significant difference in business model characteristics for entrepreneurship success between

Egypt and Nigeria.

$\mathrm{H}_{6}$ : There is a significant difference in the future directions of entrepreneurship between Egypt and Nigeria.

$\mathrm{H}_{7}$ : There is a significant difference in the future directions of entrepreneurship according to age.

\subsection{Study objective}

This study investigates the obstacles, success factors, and business model for entrepreneurship, as well as their future directions in Africa in general and in Egypt and Nigeria in particular.

\subsection{Study importance}

Entrepreneurship is one of the factors leading to growth of both the economy and national assets. (Lordkipanidze et al., 2005) Entrepreneurship can change the lifestyle and create value, jobs, and conditions for a prosperous society. Therefore, the current study focuses on entrepreneurship, its obstacles and success factors, and whether it plays an important role in achieving sustainable development and sustained economic growth.

\section{Data Description and Hypotheses Testing}

\subsection{Data collection}

The purpose of this study is to investigate the attitudes of founders, investors, corporate managers, academics, and graduates who seek a new project in Egypt and Nigeria to identify the determinants of entrepreneurship, that is, its obstacles and success factors. The different dimensions of obstacles and success, as reported in this study, were identified by reviewing prior literature on this issue, in addition to conducting interviews with stakeholders for the first stage of the study (building the framework of the study). But in the second stage of this study (hypothesis test) used the questionnaire instrument; 466 questionnaires were sent, and 395 questionnaires were received, with a response rate of $84.76 \%$. Table 1 summarizes the number of participants in the survey. The study uses parametric and non-parametric tests to obtain statistical inferences for the study hypotheses.

Table 1. Survey participants

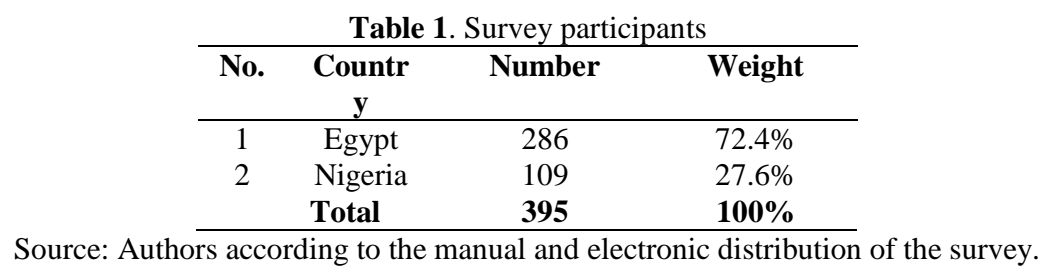

\subsection{Reliability statistics}

The Cronbach's alpha coefficient of the received questionnaires was 0.8059 , and the standardized-item alpha was 0.8209 . Thus, the study found indicators of stability of the statistical tests' results. 


\section{ENTREPRENEURSHIP AND SUSTAINABILITY ISSUES}

ISSN 2345-0282 (online) http://jssidoi.org/jesi/

2019 Volume 7 Number 2 (December)

http://doi.org/10.9770/jesi.2019.7.2(12)

\subsection{Data description}

The current survey has four main dimensions: entrepreneurship obstacle factors, entrepreneurship success factors, business model characteristics for entrepreneurship success, and future directions of entrepreneurship. That the sample from Egypt and Nigeria have a normal distribution; so the study ability to Applied Kruskal-Wallis test and One-way analysis of variance (ANOVA) test; next sections show Mean, standard deviation and coefficient of variation for each statement.

\subsubsection{Entrepreneurship obstacles factors}

Table 3 presents data on the entrepreneurship obstacle factors. This table displays values of the mean, standard deviation, and coefficient of variation.

Table 2. Descriptive statistics of entrepreneurship obstacles factors

\begin{tabular}{|c|c|c|c|c|}
\hline No. & Statement: Entrepreneurship obstacle factors & Mean & $\begin{array}{c}\text { Std. } \\
\text { deviation }\end{array}$ & $\begin{array}{c}\text { Coefficient of } \\
\text { variation }\end{array}$ \\
\hline $\mathbf{1}$ & Lack of legislative support for the start-up & 3.850633 & 1.020335545 & 0.264979 \\
\hline 2 & $\begin{array}{l}\text { Lack of legislative support for technology } \\
\text { mechanisms }\end{array}$ & 3.883544 & 0.896472271 & 0.230839 \\
\hline 3 & $\begin{array}{l}\text { Lack of legislative support for non-traditional } \\
\text { companies }\end{array}$ & 3.693671 & 1.024985053 & 0.277498 \\
\hline 4 & Weak local technology & 3.724051 & 0.975488318 & 0.261943 \\
\hline 5 & Difficulties in bank financing & 3.835443 & 1.000385455 & 0.260827 \\
\hline 6 & $\begin{array}{l}\text { Difficulties in non-bank financing such as in } \\
\text { leasing }\end{array}$ & 3.774684 & 1.006258128 & 0.266581 \\
\hline 7 & Difficulties in listing on the stock exchange & 3.762025 & 1.019642592 & 0.271036 \\
\hline 8 & Lack of management skills & 3.893671 & 1.051387984 & 0.270025 \\
\hline 9 & Lack of accounting skills & 3.531041 & 1.079387922 & 0.305685 \\
\hline 10 & Improper accounting standards & 3.465427 & 1.094854551 & 0.315936 \\
\hline 11 & Lack of government support & 3.987342 & 0.943770262 & 0.236692 \\
\hline 12 & Lack of market statistics & 4.065823 & 0.966820903 & 0.237792 \\
\hline D1 & Entrepreneurship obstacles & 3.847088608 & 0.529160219 & 0.137548228 \\
\hline
\end{tabular}

Source: Statistical Package for the Social Sciences output.

According to Table 2, the participants were in agreement regarding the entrepreneurship obstacles at the rate of $86.7 \%$. The agreement was the highest for 'Lack of legislative support for technology mechanisms' but the lowest for 'Improper accounting standards'.

\subsubsection{Entrepreneurship success factors}

Table 3 presents the data on entrepreneurship success factors. This table displays values of the mean, standard deviation, and coefficient of variation.

Table 3. Descriptive statistics of entrepreneurship success factors

\begin{tabular}{clccc}
\hline No. & Statement: Entrepreneurship success factors & Mean & $\begin{array}{c}\text { Std. } \\
\text { deviation }\end{array}$ & $\begin{array}{c}\text { Coefficient of } \\
\text { variation }\end{array}$ \\
\hline $\mathbf{1}$ & Understanding the economic environment & 3.941772152 & 0.973846786 & 0.247058112 \\
$\mathbf{2}$ & Determining market gaps & 3.99821597 & 0.872594591 & 0.218245987 \\
$\mathbf{3}$ & Ensuring capital adequacy & 3.875949367 & 0.919227107 & 0.237161794 \\
$\mathbf{4}$ & Creating a stable cash flow & 3.989873418 & 0.928892542 & 0.232812534 \\
$\mathbf{5}$ & Adding value to the society & 4.091139241 & 0.932654891 & 0.227969481 \\
$\mathbf{D 2}$ & Entrepreneurship success & 3.979746835 & 0.601516642 & 0.151144449 \\
\hline
\end{tabular}

Source: Statistical Package for the Social Sciences output. 
According to Table 3, the participants were in agreement regarding the entrepreneurship success factors at the rate of $84.9 \%$. The agreement was the highest for 'Determining market gaps', but lower for 'Understanding the economic environment'.

\subsubsection{Business model characteristics for entrepreneurship success}

Table 4 presents data on the business model characteristics for entrepreneurship success. This table presents values of the mean, standard deviation, and coefficient of variation.

Table 4. Descriptive statistics of nusiness model characteristics for entrepreneurship success

\begin{tabular}{clccc}
\hline No. & $\begin{array}{c}\text { Statement: Business model characteristics for } \\
\text { entrepreneurship success }\end{array}$ & Mean & $\begin{array}{c}\text { Std. } \\
\text { deviation }\end{array}$ & $\begin{array}{c}\text { Coefficient of } \\
\text { variation }\end{array}$ \\
\hline $\mathbf{1}$ & Added value for the society & 3.873418 & 1.103376091 & 0.284858533 \\
$\mathbf{2}$ & Benefits for clients & 3.936709 & 0.939026553 & 0.238530861 \\
$\mathbf{3}$ & Benefits for suppliers & 3.95443 & 0.90567829 & 0.229028761 \\
$\mathbf{4}$ & Benefits for investors and stockholders & 3.875949 & 0.835326495 & 0.215515327 \\
$\mathbf{5}$ & Benefits for the founder & 4.002532 & 0.965124684 & 0.241128558 \\
$\mathbf{D 3}$ & $\begin{array}{l}\text { Business model characteristics for } \\
\text { entrepreneurship success }\end{array}$ & 3.928608 & 0.644592371 & 0.164076548 \\
\hline
\end{tabular}

Source: Statistical Package for the Social Sciences output.

According to Table 4, the participants were in agreement regarding the business model characteristics for entrepreneurship success at the rate of $83.6 \%$. The agreement was the highest for 'Benefits for investors and stockholders' but lower for 'Added value for the society'.

\subsubsection{Future directions of entrepreneurship}

Table 5 presents data on the future directions of entrepreneurship. This table presents values of the mean, standard deviation, and coefficient of variation.

Table 5. Descriptive statistics of future directions of entrepreneurship

\begin{tabular}{clccc}
\hline No. & \multicolumn{1}{c}{$\begin{array}{c}\text { Statement: Future directions of } \\
\text { entrepreneurship }\end{array}$} & Mean & $\begin{array}{c}\text { Std. } \\
\text { deviation }\end{array}$ & $\begin{array}{c}\text { Coefficient of } \\
\text { variation }\end{array}$ \\
\hline $\mathbf{1}$ & Industrial production & 3.807594937 & 1.053610201 & 0.276712785 \\
$\mathbf{2}$ & Agricultural production & 3.448101266 & 1.163844142 & 0.337531892 \\
$\mathbf{3}$ & Services & 4.035443038 & 1.019485037 & 0.252632741 \\
D4 & Future directions of entrepreneurship & 3.763713079 & 0.788295477 & 0.20944622 \\
\hline \multicolumn{3}{c}{ Source: Statistical Package for the Social Sciences output. }
\end{tabular}

Source: Statistical Package for the Social Sciences output.

According to Table 5, the participants were in agreement regarding the future directions of entrepreneurship at the rate of $79.06 \%$. The agreement was the highest for 'services' but lower for 'Agricultural production'.

\subsection{Hypotheses testing}

This study used a one-way analysis of variance test as well as a Kruskal-Wallis test to examine the hypotheses. 


\subsubsection{Examining the difference in entrepreneurship banking obstacles between Egypt and Nigeria}

Table 6. One-way analysis of variance (ANOVA) output for entrepreneurship banking obstacles for Egypt and Nigeria

\begin{tabular}{|c|c|c|c|c|c|c|}
\hline & & $\begin{array}{c}\text { Sum of } \\
\text { Squares }\end{array}$ & DF & $\begin{array}{c}\text { Mean } \\
\text { Square }\end{array}$ & $\mathbf{F}$ & Sig. \\
\hline \multirow{3}{*}{$\begin{array}{c}\text { Entrepreneurship } \\
\text { banking } \\
\text { obstacles }\end{array}$} & $\begin{array}{c}\text { Between } \\
\text { Groups }\end{array}$ & 0.824 & 1 & 0.824 & \multirow[t]{3}{*}{0.823} & \multirow[t]{3}{*}{0.365} \\
\hline & Within Groups & 393.48 & 393 & \multirow[t]{2}{*}{1.001} & & \\
\hline & Total & 394.304 & 394 & & & \\
\hline
\end{tabular}

The previous statistical results show $\mathrm{F}$ value was (0.823); it isn't significant at 0.05 levels. So; table 6 show the general tendency to face the same entrepreneurship banking obstacles. In other words, this study did not find a difference in entrepreneurship banking obstacles between Egypt and Nigeria.

\subsubsection{Examining the difference in entrepreneurship non-banking obstacles between Egypt and Nigeria}

The next statistical results show F value was (4.469); it is significant at 0.05 levels. So; table 7 shows the general tendency to face different entrepreneurship non-banking obstacles. In other words, this study found a difference in entrepreneurship non-banking obstacles between Egypt and Nigeria. This difference is significant at the 0.05 level.

Table 7. One-way analysis of variance (ANOVA) output for entrepreneurship non- banking obstacles between Egypt \& Nigeria

\begin{tabular}{|c|c|c|c|c|c|c|}
\hline & & $\begin{array}{c}\text { Sum of } \\
\text { Squares }\end{array}$ & DF & $\begin{array}{c}\text { Mean } \\
\text { Square }\end{array}$ & $\mathbf{F}$ & Sig. \\
\hline \multirow{2}{*}{$\begin{array}{l}\text { Entrepreneurship } \\
\text { non- banking } \\
\text { obstacles }\end{array}$} & $\begin{array}{l}\text { Between } \\
\text { Groups }\end{array}$ & 3.143 & 1 & 3.143 & 4.469 & 0.035 \\
\hline & $\begin{array}{c}\text { Within Groups } \\
\text { Total }\end{array}$ & $\begin{array}{l}276.411 \\
279.554 \\
\end{array}$ & $\begin{array}{l}393 \\
394\end{array}$ & 0.703 & & \\
\hline
\end{tabular}

\subsubsection{Examining the difference in entrepreneurship non-financial obstacles between Egypt and Nigeria}

The next statistical results show $\mathrm{F}$ value was (10.012); it is significant at 0.01 levels. So; table 8 show the general tendency to face different entrepreneurship non-financial obstacles. In other words, this study found a difference in entrepreneurship non-financial obstacles between Egypt and Nigeria. This difference is significant at the 0.01 level.

Table 8. One-way analysis of variance (ANOVA) output for the difference in entrepreneurship non-financial obstacles between Egypt and Nigeria

\begin{tabular}{|c|c|c|c|c|c|c|}
\hline & & $\begin{array}{c}\text { Sum of } \\
\text { Squares }\end{array}$ & DF & $\begin{array}{c}\text { Mean } \\
\text { Square }\end{array}$ & $\mathbf{F}$ & Sig. \\
\hline \multirow{3}{*}{$\begin{array}{c}\text { Entrepreneurship } \\
\text { non-financial } \\
\text { obstacles }\end{array}$} & $\begin{array}{c}\text { Between } \\
\text { Groups }\end{array}$ & 3.288 & 1 & 3.288 & \multirow[t]{3}{*}{10.012} & \multirow[t]{3}{*}{0.002} \\
\hline & Within Groups & 129.062 & 393 & \multirow[t]{2}{*}{0.328} & & \\
\hline & Total & 132.350 & 394 & & & \\
\hline
\end{tabular}

\subsubsection{Examining the difference in entrepreneurship success factors between Egypt and Nigeria}

The next statistical results show F value was (0.170); it isn't significant at 0.05 levels. So; table 9 show the general tendency to have the same entrepreneurship success factors. In other words, this study did not find a difference in entrepreneurship success factors between Egypt and Nigeria. 
Table 9. One-way analysis of variance (ANOVA) output for entrepreneurship success factors between Egypt and Nigeria.

\begin{tabular}{ccccccc}
\hline & & $\begin{array}{c}\text { Sum of } \\
\text { Squares }\end{array}$ & DF & $\begin{array}{c}\text { Mean } \\
\text { Square }\end{array}$ & F & Sig. \\
\hline \multirow{2}{*}{$\begin{array}{c}\text { Entrepreneurship } \\
\text { success factors }\end{array}$} & $\begin{array}{c}\text { Between } \\
\text { Groups }\end{array}$ & 0.06175 & 1 & 0.0617 & 0.170 & 0.680 \\
& $\begin{array}{c}\text { Within Groups } \\
\text { Total }\end{array}$ & $\begin{array}{c}142.496 \\
142.558\end{array}$ & 393 & 0.3625 & 394 & \\
\hline \multicolumn{7}{c}{ Source: Statistical Package for the Social Sciences output. }
\end{tabular}

\subsubsection{Examining the difference in business model characteristics for entrepreneurship success between Egypt and Nigeria}

The next statistical results show F value was (0.209); it isn't significant at 0.05 levels. So; table 10 show the general tendency to have the same business model characteristics for entrepreneurship success. In other words, the study did not find a difference in business model characteristics for entrepreneurship success between Egypt and Nigeria.

Table 10. One-way analysis of variance (ANOVA) output for business model characteristics for entrepreneurship success factors

\begin{tabular}{ccccccc}
\hline & Sum of & DF & $\begin{array}{c}\text { Mean } \\
\text { Square }\end{array}$ & F & Sig. \\
\hline $\begin{array}{c}\text { Business } \\
\text { model }\end{array}$ & $\begin{array}{c}\text { Between } \\
\text { Groups }\end{array}$ & 0.08686 & 1 & 0.08685 & 0.209 & 0.648 \\
characteristics & $\begin{array}{c}\text { Within Groups } \\
\text { Total }\end{array}$ & $\begin{array}{l}163.620 \\
163.707\end{array}$ & 393 & 0.41633 & & \\
\hline \multicolumn{7}{c}{ Source: Statistical Package for the Social Sciences output. }
\end{tabular}

\subsubsection{Examining the difference in future directions of entrepreneurship between Egypt and Nigeria}

The next statistical results show $\mathrm{F}$ value was (0.051); it isn't significant at 0.05 levels. So; table 11 show a general tendency to have the same future directions of entrepreneurship. In other words, this study did not find a difference in future directions of entrepreneurship between Egypt and Nigeria.

Table 11. One-way analysis of variance (ANOVA) output for future directions of entrepreneurship

\begin{tabular}{|c|c|c|c|c|c|c|}
\hline & & $\begin{array}{c}\text { Sum of } \\
\text { Squares }\end{array}$ & DF & $\begin{array}{c}\text { Mean } \\
\text { Square }\end{array}$ & $\mathbf{F}$ & Sig. \\
\hline \multirow{3}{*}{$\begin{array}{c}\text { Future } \\
\text { directions of } \\
\text { entrepreneurship }\end{array}$} & $\begin{array}{c}\text { Between } \\
\text { Groups }\end{array}$ & 0.03155 & 1 & 0.0315 & \multirow[t]{3}{*}{0.051} & \multirow[t]{3}{*}{0.822} \\
\hline & Within Groups & 244.8038 & 393 & \multirow[t]{2}{*}{0.6229} & & \\
\hline & Total & 244.8354 & 394 & & & \\
\hline
\end{tabular}

\subsubsection{Examining the effect of age on the future directions of industrial entrepreneurship}

The next statistical results show Chi-Square value was (16.831); it is significant at 0.01 levels. So; table 12 show the general tendency to have different future directions of industrial entrepreneurship. In other words, the study found a difference in future directions of industrial entrepreneurship according to age that is significant at the 0.01 level. 
Table 12. Kruskal-Wallis output for the effect of age on future directions of industrial entrepreneurship

\begin{tabular}{cc}
\hline & The future directions of industrial entrepreneurship \\
\hline $\begin{array}{c}\text { Chi-Square } \\
\text { df }\end{array}$ & 16.831 \\
Asymp. Sig. & 4 \\
a & Kruskal Wallis Test \\
b & Grouping Variable: C1 \\
\multicolumn{2}{c}{ Source: Statistical Package for the Social Sciences output. }
\end{tabular}

\subsubsection{Examining the effect of age on future directions of agricultural entrepreneurship}

The next statistical results show Chi-Square value was (19.294); it is significant at 0.01 levels. So; Table 13 show the general tendency to have different future directions of agricultural entrepreneurship. In other words, the study found a difference in future directions of agricultural entrepreneurship according to age that is significant at the 0.01 level (Table 14).

Table 13. Kruskal-Wallis output for the effect of age on the future directions of agricultural entrepreneurship The future directions of agricultural entrepreneurship

\begin{tabular}{cc}
$\begin{array}{c}\text { Chi-Square } \\
\text { df }\end{array}$ & 19.294 \\
Asymp. Sig. & 4 \\
a & Kruskal Wallis Test \\
b & Grouping Variable: C1 \\
\multicolumn{2}{c}{ Source: Statistical Package for the Social Sciences output. }
\end{tabular}

\subsubsection{Examining the effect of age on future directions of service entrepreneurship}

The next statistical results show Chi-Square value was (22.160); it is significant at 0.01 levels. Table 14 show the general tendency to have differences in future directions of service entrepreneurship. In other words, the study found a difference in future directions of service entrepreneurship according to age, which is significant at the 0.05 level (Table 15).

Table 14. Kruskal-Wallis output for the effect of age on the future directions of services entrepreneurship

\begin{tabular}{rr}
\hline $\begin{array}{c}\text { Chi-Square } \\
\text { df }\end{array}$ & The future directions of services entrepreneurship \\
Asymp. Sig. & 22.160 \\
a & Kruskal Wallis Test \\
b & Grouping Variable: C1 \\
Source: Statistical Package for the Social Sciences output.
\end{tabular}

\section{Conclusions and Recommendations}

\subsection{Study Conclusions}

There is often confusion between the concepts of SMEs and entrepreneurship (Lucky and Olusegun; 2012), which can be addressed by the convergence of research topics and characteristics. According to current study, entrepreneurship has the ability to add a value chain to the society, which is not generally true for SMEs. This finding agrees with Lee et al. (2012) and Kuivalainen et al. (2012). In addition, this study finds that entrepreneurship is valid even for non-profit projects. This agrees with Morris et al. (2007).

This study provides a framework for the determinants of entrepreneurship, classified into three groups of factors: obstacle factors, success factors, and business model characteristics. This study assumes that there is a relationship between the second and third groups, which adds value to the society. 


\section{ENTREPRENEURSHIP AND SUSTAINABILITY ISSUES}

ISSN 2345-0282 (online) http://jssidoi.org/jesi/

2019 Volume 7 Number 2 (December)

http://doi.org/10.9770/jesi.2019.7.2(12)

Participants of the study were in agreement regarding the entrepreneurship obstacles - which include financial and non-financial obstacles - at the rate of $86.7 \%$. However, the rate of agreement for success factors-which include understanding the economic environment, determining market gaps, ensuring capital adequacy, and creating a stable cash flow-was $84.9 \%$. Finally, the rate of agreement for business model characteristics-which include benefits for clients, suppliers, founders, investor, and other stakeholders-was $83.6 \%$.

According to the stakeholders, there is no difference in entrepreneurship banking obstacles between Egypt and Nigeria, but a difference exists in entrepreneurship nonbanking and non-financial obstacles, which is significant at the 0.05 level.

The banking sector in Egypt and Nigeria has maintains effectiveness according to the Basel I, II, and III norms according to development of Regulatory Restrictions (Ozili, 2015; Helmy and Wagdi, 2019). The reason for the difference in nonbanking obstacles is likely the level difference of efficiency of the Egyptian Exchange and the Nigerian Stock Exchange (Jefferis and Smith 2005) and non-banking services such as leasing and securitization, since traditional bank lending has slowed down, it has become essential to develop non-bank funding (Rateiwa and Aziakpono, 2017), but the reason for the difference in nnon-financial obstacles back to the differences in legal environments and levels of corruption between Egypt and Nigeria (Cilliers et al., 2015).

The study did not find differences in entrepreneurship success factors, business model characteristics for entrepreneurship success, and future directions of entrepreneurship between Egypt and Nigeria. The similarity of results can be explained by the similarity in the two countries' education level and investment awareness.

\subsection{Study Recommendations}

Entrepreneurship has attracted many groups of stakeholders, both individual, institutional, in addition to government of countries. Some stakeholders consider entrepreneurship as a mechanism to support sustainable development by adding value to the society. Therefore, this study recommends the participation of a number of parties to support entrepreneurship.

These parties include the following: (1) Family: Family, along with educational institutions, help develop creative skills and provide support in the ethical dimension, such as psychological support and support for entrepreneurship and participation. (2) Educational institutions: These help in developing skills in the fields of management, accounting, information technology, data analytics, creativity, negotiation, etc. (3) Government \& parliament: This helps in developing the legal environment in addition to providing tax incentives. (4) Professional institutions: Institutions such as the Financial Accounting Standards Board (FASB) and Institute of Management Accountants (IMA) aid in the development of professional and regulatory restrictions. (5) Financial authorities: These support entrepreneurship programs along with financial institutions. (6) Financial institutions: These include venture capital funds, among others. (7) Business nurseries: These provide logistic and technological support (see Figure 2). 


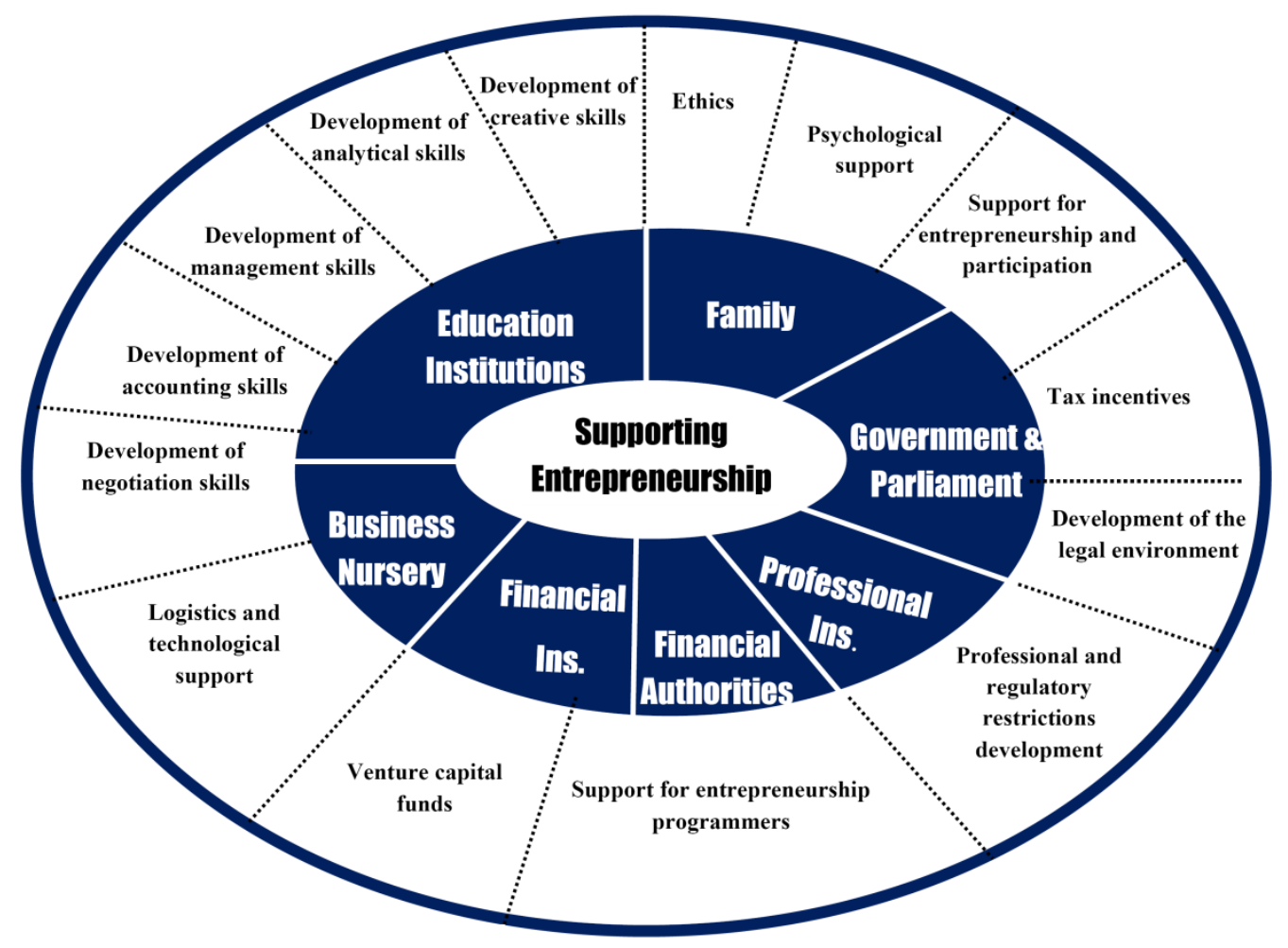

Figure 2. Framework for supporting entrepreneurship Source: Authors

Moreover, the study finds that, currently, academic research is still at the beginning stage in Africa. Therefore, in addition to a focus on the aspects of financial technology, this study suggests the following lines of future research:
a. Nonprofit entrepreneurship
b. Entrepreneurship and agency problem
c. Determinants of initial public offering entrepreneurship
d. Risk assessment of entrepreneurship
e. Impact of corruption on entrepreneurship
f. Accounting standards for entrepreneurship
g. Entrepreneurship under RegTech

In the end, African governments and international organizations should develop an entrepreneurial support program tailored to the specificities of each country, which vary in the banking system, financial markets, business ethics and business environment, as well as social characteristics. But the important dimension of entrepreneurial support program is creating a new value chain (this value be a tangible and/or intangible) with get stakeholder support; that is role of education institutions. 


\section{ENTREPRENEURSHIP AND SUSTAINABILITY ISSUES}

ISSN 2345-0282 (online) http://jssidoi.org/jesi/

2019 Volume 7 Number 2 (December)

http://doi.org/10.9770/jesi.2019.7.2(12)

\section{References}

Abou-Warda, S. H., 2016. New educational services development: framework for technology entrepreneurship education at universities in Egypt. International Journal of Educational Management, 30(5), 698-717. https://doi.org/10.1108/IJEM-11-2014-0142

Adjei, E.K., Eriksson, R.H., Lindgren, U., Holm, E., 2019. Familial relationships and firm performance: the impact of entrepreneurial family relationships. Entrepreneurship \& Regional Development 31(5-6), 357-377. https://doi.org/10.1080/08985626.2018.1514074

Bitzenis, A., Nito, E., 2005. Obstacles to entrepreneurship in a transition business environment: the case of Albania. Journal of Small Business and Enterprise Development 12(4), 564-578. https://doi.org/10.1108/14626000510628234

Chikha, I. B., \& Jarboui, A., 2018. Influence of personal traits on social entrepreneurship intention: an empirical study related to Tunisia. International Journal of Social Entrepreneurship and Innovation, 5(2), 148-165. https://doi.org/10.1504/IJSEI.2018.097718

Cilliers, J., Schunemann, J., \& Moyer, J. D. (2015). Power and influence in Africa: Algeria, Egypt, Ethiopia, Nigeria and South Africa. Institute for Security Studies Papers, 2015(14), 28. https://hdl.handle.net/10520/EJC168193

Covin, J.G., Slevin, D.P., 1991. A conceptual model of entrepreneurship as firm behavior. Entrepreneurship Theory and Practice 16(1), 726. https://doi.org/10.1177\%2F104225879101600102

Dakung, R. J., Orobia, L., Munene, J. C., \& Balunywa, W., 2017. The role of entrepreneurship education in shaping entrepreneurial action of disabled students in Nigeria. Journal of Small Business \& Entrepreneurship, 29(4), 293-311. https://doi.org/10.1080/08276331.2017.1312217

Donald, K.F., Goldsby, M.G., 2004. Corporate entrepreneurs or rogue middle managers? A framework for ethical corporate entrepreneurship. Journal of Business Ethics 55(1), 13-30. https://doi.org/10.1007/s10551-004-1775-3

Elert, N., Andersson, F. W., \& Wennberg, K., 2015. The impact of entrepreneurship education in high school on long-term entrepreneurial performance. Journal of Economic Behavior \& Organization, 111, 209-223. https://07101rb4a-1103-y-https-doiorg.mplbci.ekb.eg/10.1016/j.jebo.2014.12.020

Ensher, E.A., Murphy, S.E., Vance, C.M., 2000. Mentoring and self-management career strategies for entrepreneurs. The International Journal of Entrepreneurship and Innovation 1(2), 99-108. https://doi.org/10.5367\%2F000000000101298595

Fatoki, O.O., Chindoga, L., 2011. An investigation into the obstacles to youth entrepreneurship in South Africa. International Business Research 4(2), 161-169. https://doi.org/10.5539/ibr.v4n2p161

Ghouse, S.M., McElwee, G., Durrah, O., 2019. Entrepreneurial success of cottage-based women entrepreneurs in Oman. International Journal of Entrepreneurial Behavior \& Research 25(3), 480-498. https://doi.org/10.1108/IJEBR-10-2018-0691

Hattab, H. W., 2014. Impact of entrepreneurship education on entrepreneurial intentions of university students in Egypt. The Journal of Entrepreneurship, 23(1), 1-18. https://doi.org/10.1177\%2F0971355713513346

Helmy, A., \& Wagdi, O. (2019). Three-Dimensional Analysis of Bank Profit with the Development of Regulatory Restrictions: Evidence from Egypt. International Journal of Economics and Finance, 11(3). https://doi.org/10.5539/ijef.v11n3p12

Hendrajaya, H., Widodo, J., Rachman, M., Raharjo, T.J., 2019. Determinant model of student entrepreneurship awareness. The Journal of Educational Development 7(1), 1-15. https://doi.org/10.15294/jed.v7i1.29324

Jones, G.R., Butler, J.E., 1992. Managing internal corporate entrepreneurship: an agency theory perspective. Journal of Management 18(4), 733-749. https://doi.org/10.1177\%2F014920639201800408

Kojo Oseifuah, E., 2010. Financial literacy and youth entrepreneurship in South Africa. African journal of Economic and management studies, 1(2), 164-182. https://doi.org/10.1108/20400701011073473 


\section{ENTREPRENEURSHIP AND SUSTAINABILITY ISSUES}

ISSN 2345-0282 (online) http://jssidoi.org/jesi/

2019 Volume 7 Number 2 (December)

http://doi.org/10.9770/jesi.2019.7.2(12)

Kuivalainen, O., Sundqvist, S., Saarenketo, S., McNaughton, R., Olejnik, E., Swoboda, B., 2012. SMEs' internationalisation patterns: descriptives, dynamics and determinants. International Marketing Review 29(5), 466-495. https://doi.org/10.1108/02651331211260340

Kwong, C.C., Cheung, C.W., Manzoor, H., Rashid, M.U., 2019. Entrepreneurship through Bricolage: a study of displaced entrepreneurs at times of war and conflict. Entrepreneurship \& Regional Development 31(5-6), 435-455. https://doi.org/10.1080/08985626.2018.1541592

Ladzani, W.M., Van Vuuren, J.J., 2002. Entrepreneurship training for emerging SMEs in South Africa. Journal of Small Business Management 40(2), 154-161. https://doi.org/10.1111/1540-627X.00047

Lee, Y., Shin, J., Park, Y., 2012. The changing pattern of SME's innovativeness through business model globalization. Technological Forecasting and Social Change 79(5), 832-842. https://doi.org/10.1016/j.techfore.2011.10.008

Lordkipanidze, M., Brezet, H., Backman, M., 2005. The entrepreneurship factor in sustainable tourism development. Journal of Cleaner Production 13(8), 787-798. https://doi.org/10.1016/j.jclepro.2004.02.043

Lucky, E.O. and Olusegun, A.I., 2012. Is small and medium enterprises (SMEs) an entrepreneurship. International Journal of Academic Research in Business and Social Sciences, 2(1), pp.487-496. http://www.hrmars.com/admin/pics/545.pdf

Markussen, S., \& Røed, K., 2017. The gender gap in entrepreneurship-The role of peer effects. Journal of Economic Behavior \& Organization, 134, 356-373. https://07101rb4a-1103-y-https-doi-org.mplbci.ekb.eg/10.1016/j.jebo.2016.12.013

McClelland, D.C., 1987. Characteristics of successful entrepreneurs. The Journal of Creative Behavior 21(3), 219-233. https://doi.org/10.1002/j.2162-6057.1987.tb00479.x

Michael, S.C., Pearce, J.A., 2009. The need for innovation as a rationale for government involvement in entrepreneurship. Entrepreneurship and Regional Development 21(3), 285-302. https://doi.org/10.1080/08985620802279999

Morris, M. H., Coombes, S., Schindehutte, M., \& Allen, J. (2007). Antecedents and outcomes of entrepreneurial and market orientations in a non-profit context: Theoretical and empirical insights. Journal of Leadership \& Organizational Studies, 13(4), 12-39. https://doi.org/10.1177\%2F10717919070130040401

Ozili, P. K. (2015). Determinants of bank profitability and Basel capital regulation: Empirical evidence from Nigeria. Research Journal of Finance and Accounting, 6(2), 124-131. https://www.iiste.org/Journals/index.php/RJFA/article/view/19184/19741

Peberdy, S., 2000. Mobile entrepreneurship: Informal sector cross-border trade and street trade in South Africa. Development Southern Africa, 17(2), 201-219. https://doi.org/10.1080/713661400

Ramoglou, S., Tsang, E.W., 2017. Accepting the unknowables of entrepreneurship and overcoming philosophical obstacles to scientific progress. Journal of Business Venturing Insights 8, 71-77. https://doi.org/10.1016/j.jbvi.2017.07.001

Rateiwa, R., \& Aziakpono, M. J. (2017). Non-bank financial institutions and economic growth: Evidence from Africa's three largest economies. South African Journal of Economic and Management Sciences, 20(1), 1-11. http://dx.doi.org/10.4102/sajems.v20i1.1545

Ríos-Manríquez, M., Sánchez-Fernández, M.D., Montero, E.I.C., 2018. Entrepreneurship in emerging economies: a microenterprise case. In: Carvalho, L.C., Rego, C., Lucas, M.R., Sánchez-Hernández, M.I., Noronha, A.B. (Eds.). Entrepreneurship and Structural Change in Dynamic Territories. Cham, Switzerland: Springer, 317-351. https://doi.org/10.1007/978-3-319-76400-9_17

Robson, P. J., Haugh, H. M., \& Obeng, B. A., 2009. Entrepreneurship and innovation in Ghana: enterprising Africa. Small Business Economics, 32(3), 331-350. https://doi.org/10.1007/s11187-008-9121-2

Salem, I. E., \& Mobarak, N. M., 2019. The influence of demographic characteristics of hospitality alumni on entrepreneurship factors in Egypt. Journal of Human Resources in Hospitality \& Tourism, 18(2), 215-239. https://doi.org/10.1080/15332845.2019.1558484

Sofer, M., Saada, M.T., 2017. Entrepreneurship of women in the rural space in Israel: catalysts and obstacles to enterprise development. Sociologia Ruralis 57, 769-790. https://doi.org/10.1111/soru.12125 


\section{ENTREPRENEURSHIP AND SUSTAINABILITY ISSUES}

ISSN 2345-0282 (online) http://jssidoi.org/jesi/

2019 Volume 7 Number 2 (December)

http://doi.org/10.9770/jesi.2019.7.2(12)

Timmons, J.A., 1978. Characteristics and role demands of entrepreneurship. American Journal of Small Business 3(1), 5-17. https://doi.org/10.1177\%2F104225877800300102

Tripathy, M., 2019. Overcoming the major challenges in new entrepreneurship: an orientation through soft skills. SMART Journal of Business Management Studies 15(2), 38-46. http://dx.doi.org/10.5958/2321-2012.2019.00013.7

Von Graevenitz, G., Harhoff, D., \& Weber, R., 2010. The effects of entrepreneurship education. Journal of Economic Behavior \& Organization, 76(1), 90-112. https://07101rb4a-1103-y-https-doi-org.mplbci.ekb.eg/10.1016/j.jebo.2010.02.015

Osama WAGDI, PhD; Lecturer of Finance, Financial Institutions Department, Faculty of Management, Modern University for Technology and Information (MTI University), Cairo, Egypt.

ORCID ID: orcid.org/0000-0003-0451-9726

Web of Science Researcher ID: D-4898-2019

Amira HASANEEN, PhD; Lecturer of Account, Accounting Department, Faculty of Management, Modern University for Technology and Information (MTI University), Cairo, Egypt.

ORCID ID: orcid.org/0000-0001-6907-3628

Register for an ORCID ID:

https://orcid.org/register

Copyright (C) 2020 by author(s) and VsI Entrepreneurship and Sustainability Center

This work is licensed under the Creative Commons Attribution International License (CC BY).

http://creativecommons.org/licenses/by/4.0/

(c) (i) Open Access 